\title{
The development of chart based method for steel beam designs using the Russian sections
}

\author{
Tesfaldet H. Gebre
}

\author{
Peoples' Friendship University of Russia (RUDN University) \\ 6 Mikluho-Maklaya St., Moscow, 117198, Russia
}

(received: September 19, 2018; revised: November 05, 2018; accepted: November 10, 2018)

\begin{abstract}
Introduction and objectives. Russian steel construction does not cover the chart method for steel beam design and experimental works need to be implemented to investigate the behavior of the charts However, the experimental tests are expensive, tedious and time consuming to be conducted. The objective of this paper is to compare and validate the accuracy and reliability of the chart method for steel beam design by correlating moment capacity and bracing length $\left(\Phi M_{n}, L_{b}\right)$ curves between different sections and this strategy is more helpful in determining the lightest steel sections without trial and error.

Materials and methods. Alternatively, a strategy to use the AISC-LRFD's chart-based method, which plots the relationships between the flexural capacities of steel sections and their unbraced lengths of lateral bracing and weights, will be helpful in determining the lightest sections in terms of their lateral bracing requirements and moment capacity. In other words, the most optimum steel sections can be obtained without trial-and-error process.

Results. If the design with a chart-based method using the Russian steel sections is developed, it can be used to design steel beams more quickly and economically.
\end{abstract}

Keywords: lateral torsional buckling, ideal beam design, design chart, optimum steel sections

\section{Introduction}

During the analysis of steel structures, coming up with the stability resistance is one of the most crucial verification since normally the loss of stability is the governing job. In selecting a high-grade steel for a particular structure tends to produce slender structural elements so that the design of a steel beam is commonly governed by its stability and also by a constraint due to the limitation of steel variation sections available in the market. Those would represent all the issues which should be considered in steel structural designs. The trial and error processes in evaluating a range of steel sections and lateral bracing configurations with the lighter weights are needed in order to achieve an optimum design. By implementing the design based on the chart, we can find the optimum steel sections easily. The nominal flexural strength of $W$ shapes is illustrated as a function of a braced length, $L_{b}$ and the available strength is determined as $\Phi M_{n}$, which mast equal to the required strength (bending moment) $M_{u}$ [1]. It uses the curve of the bending moment capacity versus the lateral bracing distance of a wide range data of steel sections.
In the manual, the existence of a steel section with a dotted line indicates that in certain conditions and lateral bracing configurations, the performance is less optimal than the other sections indicated by a full line. Steel sections with a full line show a greater capacity but it is lighter than the weight of the steel section with a dotted line. The existence of a graphical method using a design curve would facilitate its economic steel design [1]. So, if the design curve can be created to provide the steel sections, it will certainly be widely used by those engineers since this graphical method can easily generate the optimal design of steel structures, thus saving the costs of construction.

\section{Steel beam behavior in lateral-torsional buckling}

Beams are structural elements loaded in a traverse direction, in other way beam may be defined as a member subjected essentially to bending and shear force but its behavior is dominated by its bending deformation $[2 ; 3]$. The behavior of a steel member under bending is influenced by its material properties, section slenderness, member slenderness and lateral and torsional restraints [2]. As lateral torsional stabi- 
lity is one of the special type of general buckling. It occurs when the beam is transversely loaded in the plane of the main stiffness of cross section and by the same time the transverse deflation along the beam length is not prevented. This state is characteristic by spatial deformation covering the flexural bending and the torsional displacement. Due to the bending action, the upper flange is in compression and acts like a strut. Being free to move, the compression flange will be likely to buckle sideways dragging the tension flange with it. The tension flange resists this sideways movement, therefore, as the beam buckles, the section twists with the web no longer vertical and this action is known as lateral torsional buckling (LTB) [4]. It is assumed that during deformation of the ends of beam can rotate freely with respect to the principal axes of inertia, and while rotation with respect the third axis is prevented by constraint [4]. Since the phenomena is a buckling phenomenon the strength vs slenderness curve follows the general form of the curve used for LTB [6;7]. Lateral bracing must be adequate to hold the braced beam in position. Thus, stiffness as well as strength is required. As a general rule, bracing will be adequate if each lateral brace is designed for $2 \%$ of the compressive force in the flanges of the beam it braces [8]. Two threshold values for unbraced length namely $L_{p}$ and $L_{r}$ are defined in AISC. The $L_{p}$ value provides a dividing line between plastic and inelastic buckling behavior. Similarly, the $L_{r}$ value provides a dividing line between inelastic and elastic buckling behavior. According to AISC, plastic moment capacity of a compact member can develop if the unbraced length is less than $L_{p}$ and using this value in design represent the optimum use of steel [2; 7; 9]. The member's capacity reduces linearly between $M_{p}$ and $0.7 M_{y}$ if the unbraced length is between $L_{p}$ and $L_{r}$. If the unbraced length is greater than $L_{r}$, then elastic buckling is expected to occur and the capacity can be found using elastic critical buckling moment $\left(M_{c r}\right)$. The nominal bending moment curve of the steel beam of figure 1 shows the capacity of a single steel section (W16 $\times 26)$ across a wide range of lateral bracing distances $\left(L_{b}\right)$ and shapes of the moment $\left(C_{b}\right)$ [3].

Like all buckling, the force that gets on LTB is depend on the effective length or slenderness ratio. The shape and dimensions of the cross section, the slenderness ratio and the type of loading affect the lateral torsional buckling behavior [8].

If the length is short enough, the member can develop its full plastic strength and for longer laterally unbraced lengths remains elastic buckling In-between, there is inelastic buckling. Similarly, the nominal flexural strength curve of $\mathbf{6 0 W 2}$ (Russian steel construction section) shows the assessment of capacity of a single steel section across a wide range of lateral bracing $\left(L_{b}\right)$ and shapes of the moment with $\left(C_{b}=1\right.$ and $C_{b}=1.2$ ) as shown in figure 2. In this curve, based on the required values for the limits of $L_{p}=11.1 \mathrm{ft}$ and $L_{r}=34.9 \mathrm{ft}$ their moment capacities are $M_{p}=998.4 \mathrm{ft}-\mathrm{k}$ and $M_{r}=554.5 \mathrm{ft}-\mathrm{k}$ respective. Accordingly, depending on the lateral bracing length, there are three different regions for nominal bending moment: plastic $\left(L_{b}<11.1 \mathrm{ft}\right)$, inelastic buckling $\left(11.1 \mathrm{ft}<L_{b}<34.9 \mathrm{ft}\right)$ and elastic buckling $\left(L_{b}>34.9 \mathrm{ft}\right)$.

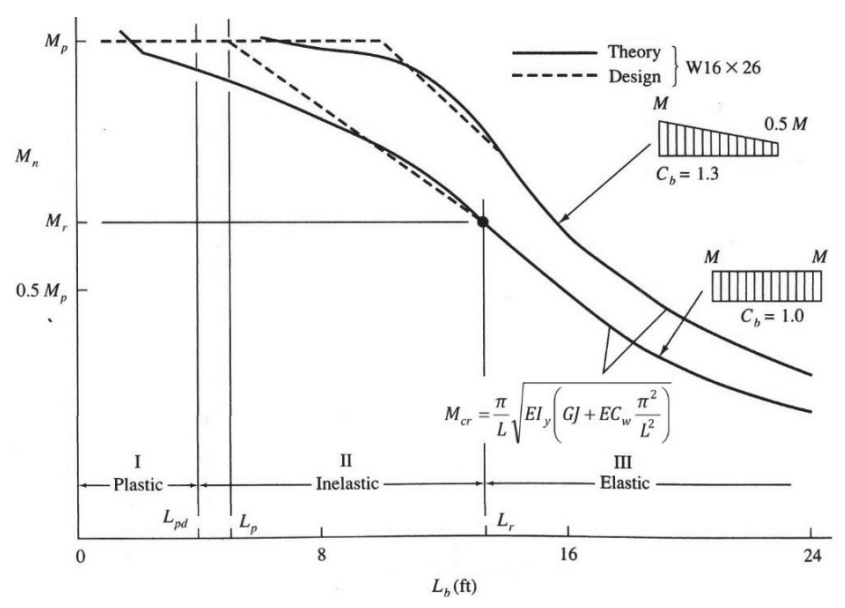

Figure 1. The influence of $L_{b}$ and $C_{b}$ to the nominal bending moment capacity of steel beam

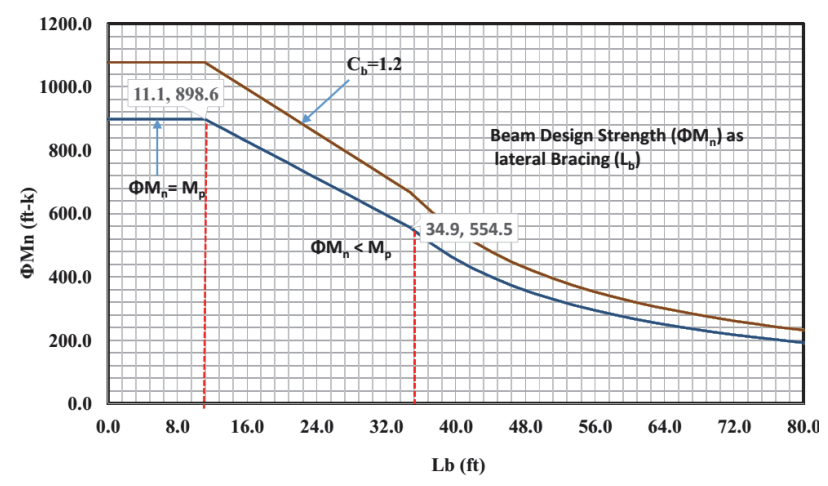

Figure 2. ФMn vs Lb for $60 \mathrm{W2}$

\section{Different types of steel beam section in Russian steel construction}

Steel beams are extremely crucial and necessary for the construction any building or structure, such as bridges, etc. They come in a wide range of sizes and shapes. The commonly used I beam sections are Ш and Б sections which are the most economical and most widely used sections. The steel section follows the following format 35Б1, 40Б1, 50Ш2, etc., the initial number is used to differentiate the Russian steel section based on the height and the alphabets are used for the type of I section example $\mathrm{b}$ stands for regular 
I-beams and $\amalg$ is used for wide flange and suffix number is used to differentiate for beams with similar height for example a group of steel sections with similar heights have a classification as $40 \amalg 1$ and $40 \amalg 2$, or 10Б1 and 10Б2 [10].

\section{The concept of curve designs}

Lateral-torsional buckling is a global buckling mode in which the in-plane deflection of a laterally unbraced beam changes to a mixed lateral deflection and twisting. According to the AISC [1]. The general form of the LTB limit state follows the typical buckling curves, as we know that the steel design manual $[1 ; 15]$ provides a wide variety of such curves for AISC steel sections only. In this paper, the method of steel design requires moment capacity curve from a wideranging of Russian steel sections available on the market because creating a local design curves using the commonly available steel section will definitely help to select the optimal steel section easily. On the curve the nominal moment capacity, $\Phi M_{n}$ placed on the ordinate and distance of lateral bracing, $L_{b}$ on the abscissa as shown in figure 3 . The curve is presented in a basic scheme of the nominal flexural strength $\left(\Phi M_{n}\right)$ as a function of the unbraced length $\left(L_{b}\right)$. The horizontal segment of the curve at the far left, between $L_{b}=0 \mathrm{ft}$ and $L_{p}$, is the range where the strength is limited by flexural yielding. In this region, the nominal strength is taken as the full plastic moment strength of the section as given by AISC Specification Equation F2-1 AISC. In the range of the curve at the far right, starting at $L_{r}$, the strength is limited by elastic buckling. The strength in this region is given by AISC Specification Equation F2-3 AISC. Between these regions, within the linear region of the curve between $M_{n}=M_{p}$ at $L_{p}$ on the left, and $M_{n}=0.7 M_{y}=0.7 F_{y} S_{x}$ at $L_{r}$ on the right, the strength is limited by inelastic buckling and the region is provided in AISC Specification Equation F2-2 [9]. The curve plotted as a heavy solid line represents the case where $C_{b}=1.0$, while the heavy dashed line represents the case where $C_{b}$ exceeds one. The point of the curve indicates that the magnitude limit is independent of the nominal moment $L_{b}$ conditions, as determined by the plastic moment of the sections $\left(\Phi M_{n}=M_{p}\right)$, if $L_{b}<L_{p}$. The point $L_{p}$ on the curve is shown as coordinate. The point of another curve showing the cross section may have been yielded at first but failed to establish its plastic moment if $L_{p}<L_{b}<L_{r}$. Steel sections with the condition $L_{b}>L_{r}$ is not efficient because the collapse (LTB) occurs in the elastic condition, while it has not undergone its plastic or yielding state, $\Phi M_{n}<M_{p}$. The curve shown in figure 2 is only for a section 60Ш2 separately so that it could be compared with another section, which would be a similar curve of a steel section in the same chart figure 3. If the nominal moment of the two curves meets and intersects at a point, the effective section based on the nominal weight of the two sections can be selected, the curve which describes the line of the economic section is a curve with a thick continuous line, while the steel sections with a broken line curve is not economical. Even though graphs and tables simplify the design process, it is equally important to understand the basic principle of steel structural designs and be accountable for the results. Necessities of the curve taken at $C_{b}=1$, which shows that the form of moments cause of LTB is considered constant, and also the strength reduction factor, $\Phi$ of 0.9 according to the AISC specification [10]. A strategic use of the moment curves to select the optimum steel section is described in figure 3. In this explanation, two choices are assumed: Section A $40 \amalg 3$ $(123.4 \mathrm{~kg} / \mathrm{m})$ and Section B $50 \amalg 1(114.4 \mathrm{~kg} / \mathrm{m})$, both displayed in the form of the moment curve $\left(\Phi M_{n}\right)$ versus lateral unbraced length $\left(L_{b}\right)$.

The nominal moment curves of the two different kinds of sections show an intersection of curves and lines which are under the other curve because it is heavier and turns into a dotted line. To design the chart needs an assessment of different cases of the $\left(\Phi M_{n}\right)$ versus $L_{b}$ of the beam sections. Case I (refer figure 3), the coordinate position with $L_{b-1}, \Phi M_{n-1}$, within the two curves, Sections A and B can be selected, but the light section is Section B (lower section). Case II with coordinates $L_{b-2}, \Phi M_{n-2}$, then Section B is the ideal section through its lightweight and strong section. Case III, the coordinate of $L_{b-3}, \Phi M_{n-3}$ is outside the two curves therefore both sections are not appropriate sections but in this case adjustment in lateral bracing can be done by reducing the value of $L_{b-3}$ to $L_{b-3}{ }_{b-3}$ then section be can be selected. Case IV with the coordinates $L_{b-4}, \Phi M_{n-4}$, it is with in one curve so section A can be selected. Case V $\left(L_{b-5}, \Phi M_{n-5}\right)$ due to its position on top of the two curves, at this moment no sufficient steel sections available and adjustment of $L_{b}$ is impossible accordingly we must use another section.

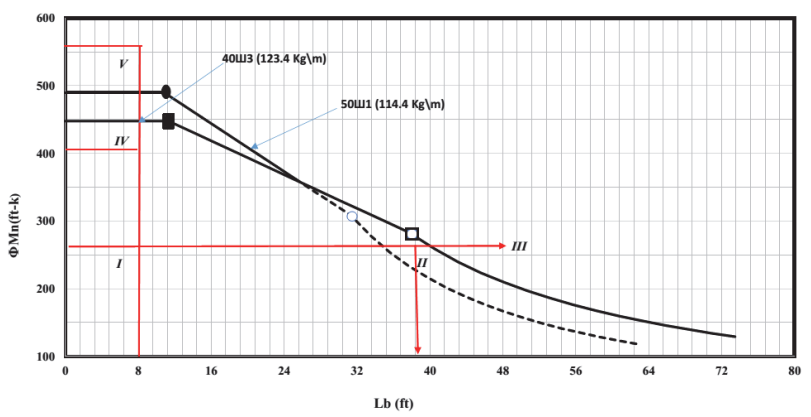

Figure 3. $\Phi M_{n}$ vs $L_{b}$ for $50 \amalg 1$ and $40 \amalg 3$ 


\section{Development of design chart to select the optimum steel section}

In beam design, tables and charts in AISC helps as design schemes based on the principle of steel structural designs, in the charts $C_{b}$ is taken as unity for uniform bending moment, and also the strength reduction factor, $\Phi_{b}$ of 0.9 according to code ${ }^{1}$. The $C_{b}$ coefficient is a modification factor that takes into account the non-uniform bending moment diagrams in the beam [13]. If the beam is subjected to a constant bending moment along the length $L_{b}$, then the developed chart is used to select the light weight and best fit Russian steel section for the given $\Phi M_{n}$ and $L_{b}$. knowing the factored moment $\left(M_{u}\right)$ including selfweight of the beam; it should be less than or equal to the design strength $\left(\Phi M_{n}\right)$. Select a shape that satisfies the flexural strength requirement based on the distance of unbraced length. The design chart can be built to calculate the capacity moment of Russian steel I-section at a certain distance of lateral bracing. Moreover, the confirmation is also done through comparison with the manual analysis to calculate the most optimum steel sections $[11 ; 13]$.

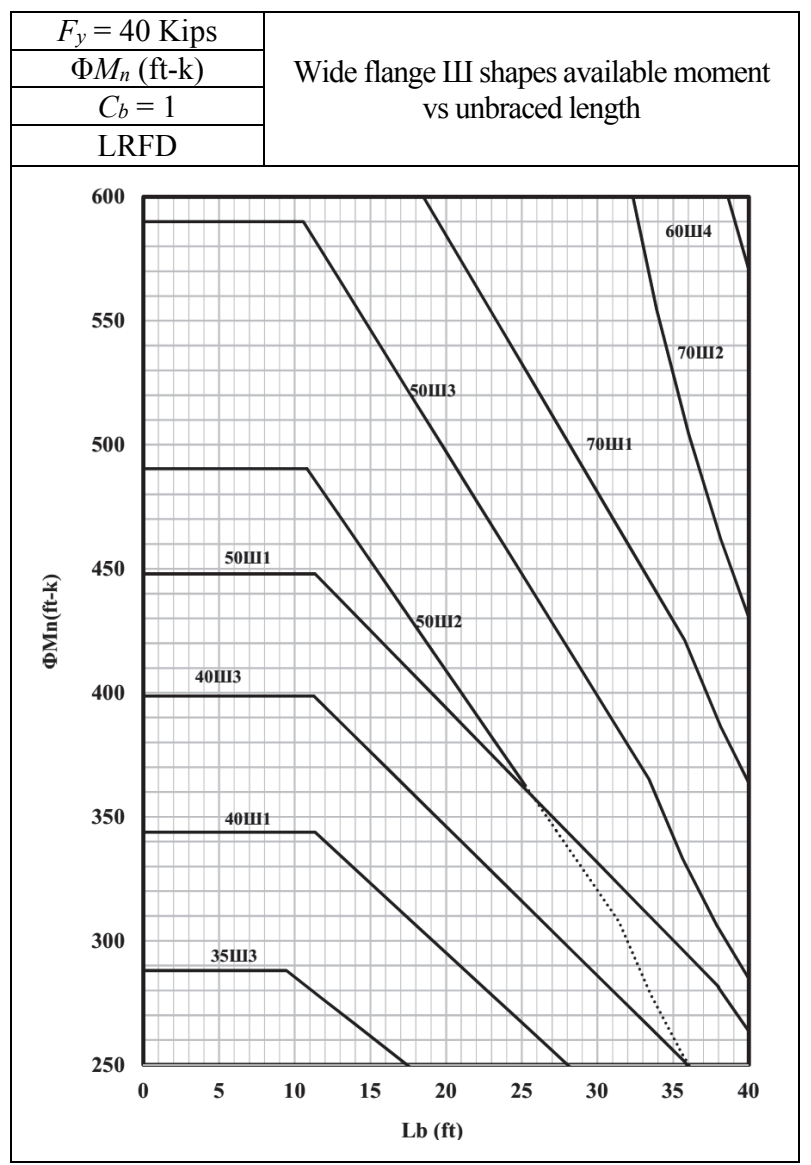

Figure 4. ФMn vs Lb design chart

\section{Chart method to select the optimum of steel section}

As the chart is developed for Russian steel I-sections, we can select the most optimal beam section based on the specified moment capacity and lateral bracing. Let we consider a beam with specified $L_{b}=15 \mathrm{ft}$ and $M_{u}=360 \mathrm{ft}-\mathrm{k}$, as our goal is to find the optimum steel sections (refer figure 5). The first step is to align a horizontal line corresponding the required moment $\left(M_{u}=360 \mathrm{ft}-\mathrm{k}\right)$ and construct another vertical line which begin from the specified lateral bracing $\left(L_{b}=15 \mathrm{ft}\right)$ then the two lines will intersect at a point. Draw a vertical line from the intersection point up to the second intersection point between the vertical line and any curve with solid line; this curve is the optimal one (40Ш3) finally dragging the horizontal line from the second point to the vertical axis to find the available moment $\left(\Phi M_{n}=376.5 \mathrm{ft}-\mathrm{k}\right)$, as the available moment is greater that moment capacity $\left(\Phi M_{n}>M_{n}\right)$ the ideal section is 40Ш3. The design of the beam with $C_{b}>1.0$, can be done, by dividing $M_{u}$ by $C_{b}$. Then, it should be compared with the nominal bending strength which is specified in the curves. The selected section does not exceed the plastic moment capacity of the cross-section available.

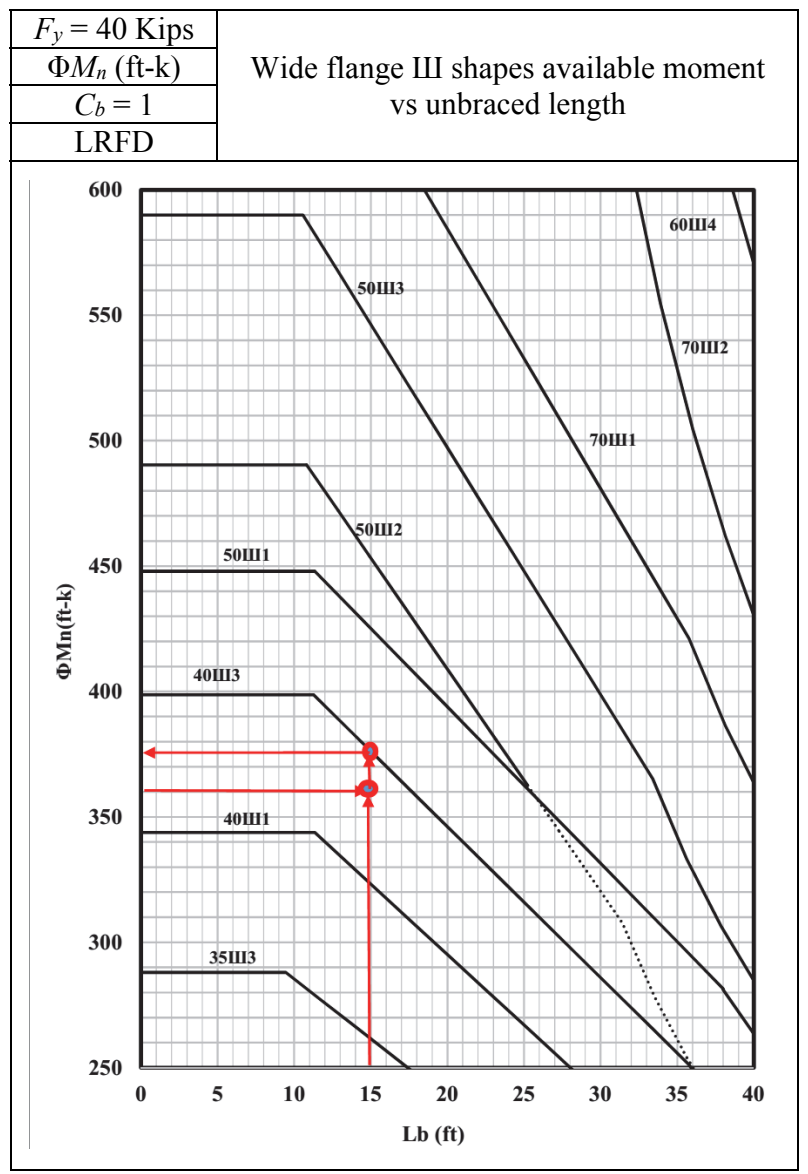

Figure 5. $\Phi M_{n}$ vs $L_{b}$ for optimal section 


\section{Conclusion}

As the objective of this paper is to compare and validate the accuracy and reliability of the chart method for steel beam design by correlating moment capacity and bracing length $\left(\Phi M_{n}, L_{b}\right)$ curves between different wide flange sections. In Russian steel construction specifications, due to the limited number of steel section the graphs are with wide gaps and there is not more overlapping of graphs to each other's. The chart is dominated by unbroken lines and it's unwieldy to select the effective section based on the nominal weight of different sections because the nominal moment of the two curves don't intersects to each other alike AISC charts. As an outcome, the Russian steel construction form of wide flange steel section list has been effectively transformed into the design curves for graphical methods. This paper concludes that the graphical method is simpler, faster, and with the same precision to the manual analysis of the non-graphical method.

(C) Gebre T.H., 2018

This work is licensed under a Creative Commons

Attribution 4.0 International License

\section{References}

1. American Institute of Steel Construction. (2011). Steel Construction Manual. 14 $4^{\text {th }}$ Edition. 183.

2. Badari B., Papp F. (2015). On Design Method of Lateral-torsional Buckling of Beams: State of the Art and a New Proposal for a General Type Design Method. Periodica Polytechnica Civil Engineering, 59(2), 179-192. DOI: 10.3311/PPci.7837

3. Salmon C.G., Johnson J.E., Malh F.A. (2009). Steel Structures: Design and Behaviour: Emphasizing Load and Resistance Factor Design, 417-431.

4. Galishnikova V.V., Pahl P.J. (2018). Analysis of frame buckling without sidesway classification. Structural Mechanics of Engineering Constructions and Buildings, 14(4), 299-312. DOI: 10.22363/1815-5235-2018-14-4-299-312

5. Brown D.G. et al. (2007). Handbook of Structural Steelwork, (55). 440.
6. Bungale S. Taranath. (2011). Structural Analysis and Design of Tall Buildings: Steel and Composite Construction. 407.

7. Farkas J., Jármai K. (2013). Cylindrical and Conical Shells. Optimum Design of Steel Structures, 46, $211-$ 230. DOI: $10.1007 / 978-3-642-36868-4$

8. Winkler R., Kindmann R., Knobloch M. (2017). Lateral Torsional Buckling Behavior of Steel Beams On the Influence of the Structural System. Structures, (11), 178-188. DOI: 10.1016/j.istruc.2017.05.007

9. Marshall T.P. et al. (2015). Design Guide for Lowand Medium-Rise Steel Buildings Institute. AI Mag., (13).

10. Building Research, Worked Examples For The Design of Steel Structures BRE SCI Based on BSI \& Eurocode 3. 1.1, 1994.

11. Bajera M., Barnat J., Pijak J. (2017). Lateral torsional buckling of selected cross-section types. Procedia Engineering, (190), 106-110. https://doi.org/10.1016/j.proeng. 2017.05.314

12. Bernuzzi C., Cordova B. (2016). Structural Steel Design to Eurocode 3 and AISC Specifications. 218 p.

13. Galishnikova V.V., Lebed E.V. (2017). A reliable method for the stability analysis of structures. J. Fundam. Appl. Sci., 9(7S), 484-496.

14. Gebre T.H., Negash N.A. (2018). The development of strength curves for compression members using three different codes: AISC, Eurocode and Russian steel construction (pp. 59-67). 208 p.

15. Williams A. (2011). Steel Structures Design ASD/ LRFD. 545.

\section{About the author}

Gebre Tesfaldet Hadgembes - $\mathrm{PhD}$ Student of the Department of Civil Engineering, Engineering Academy, Peoples' Friendship University of Russia (RUDN University) (Moscow, Russia). Research interests: computational civil engineering, frame stability analysis, lateral torsional buckling, computational mechanics of buckling systems. Contacts: e-mail - tesfaldethg@gmail.com

\section{For citation}

Gebre T.H. (2018). The development of chart based method for steel beam designs using the Russian sections. Structural Mechanics of Engineering Constructions and Buildings, 14(6), 495-501. DOI: 10.22363/1815-52352018-14-6-495-501 


\title{
Разработка графического метода проектирования стальных балок с помощью диаграмм для российского сортамента стальных профилей
}

\author{
T.X. Гебре \\ Российский университет дружбы народов \\ Российская Федерачия, 117198, Москва, ул. Миклухо-Маклая, 6
}

(поступила в редакцию: 19 сентября 2018 г.; доработана: 05 ноября 2018 г.; принята к публикации: 10 ноября 2018 г.)

Введение и цели. Графический метод расчета и проектирования стальных балок с помощью диаграмм не включен в российские нормативы по проектированию стальных конструкций, что приводит к необходимости выполнения трудоемких, длительных и дорогостоящих экспериментальных исследований. Цель данной статьи - сравнить и проверить точность и надежность метода диаграмм для проектирования стальных балок путем сопоставления кривых несущей способности по изгибающему моменту и расчетной длины $\left(\Phi M_{n}, L_{b}\right)$ стальных балок, имеющих различные поперечные сечения. Данный подход гораздо удобнее и практичнее для определения наиболее эффективных и наименее металлоемких стальных профилей, чем проектирование методом проб и ошибок.

Материалы и методы. Альтернативный подход к проектированию стальных балок с использованием графического метода AISC-LRFD на основе диаграмм изгибной несущей способности стальных профилей и их расчетной длины в боковой перпендикулярной плоскости действия изгибающего момента позволяет значительно упростить подбор наименее металлоемких и наиболее эффективных стальных балок для обеспечении их максимальной изгибной несущей способности и оптимальной длины раскрепления в боковой плоскости без использования метода проб и ошибок.

Результаты. Разработка графического метода проектирования стальных балок на основе российского сортамента прокатных профилей позволит значительно оптимизировать процесс проектирования балочных конструкций и одновременно обеспечит их максимальную эффективность и экономичность.

Ключевые слова: боковая крутильная потеря устойчивости, идеальная конструкция балки, расчетная схема, оптимальные стальные профили

\section{Список литературы}

1. Steel Construction Manual $14^{\text {th }}$ Edition / American Institute of Steel Construction. 2011. 183 p.

2. Badari B., Papp F. On Design Method of Lateraltorsional Buckling of Beams: State of the Art and a New Proposal for a General Type Design Method // Periodica Polytechnica Civil Engineering. 2015. Vol. 59. No. 2. Pp. 179-192. DOI: 10.3311/PPci.7837

3. Salmon C.G., Johnson J.E., Malh F.A. Steel Structures: Design and Behaviour: Emphasizing Load and Resistance Factor Design. 2009. Pp. 417-431.

4. Galishnikova V.V., Pahl P.J. Analysis of frame buckling without sidesway classification // Structural Mechanics of Engineering Constructions and Buildings. 2018. Vol. 14. No 4. Pp. 299-312. DOI: 10.22363/1815-5235-201814-4-299-312

5. Brown D.G. et al. Handbook of Structural Steelwork. 2007. No. 55.440 p.

6. Bungale S. Taranath. Structural Analysis and Design of Tall Buildings: Steel and Composite Construction. 2011. 407 p.
7. Farkas J., Jármai K. Cylindrical and Conical Shells // Optimum Design of Steel Structures. 2013. Vol. 46. Pp. 211-230. DOI: 10.1007/978-3-642-36868-4

8. Winkler R., Kindmann R., Knobloch M. Lateral Torsional Buckling Behavior of Steel Beams - On the Influence of the Structural System // Structures. 2017. Vol. 11. Pp. 178-188. DOI: 10.1016/j.istruc.2017.05.007

9. Marshall T.P. et al., Design Guide for Low- and Medium-Rise Steel Buildingsl Institute // AI Mag. 2015. Vol. 13.

10. Building Research, Worked Examples For The Design of Steel Structures BRE SCI Based on BSI \& Eurocode 3. 1.1. 1994.

11. Bajera M., Barnat J., Pijak J. Lateral torsional buckling of selected cross-section types // Procedia Engineering. 2017. Vol. 190. Pp. 106-110. https://doi.org/10. 1016/j.proeng.2017.05.314

12. Bernuzzi C., Cordova B. Structural Steel Design to Eurocode 3 and AISC Specifications. 2016. 218 p.

13. Galishnikova V.V., Lebed E.V. A reliable method for the stability analysis of structures // J. Fundam. Appl. Sci. 2017. Vol. 9. No. 7S. Pp. 484-496. 
14. Gebre T.H., Negash N.A. The development of strength curves for compression members using three different codes: AISC, Eurocode and Russian steel construction). 2018. 208 p. Pp. 59-67.

15. Williams A. Steel Structures Design ASD/LRFD. 2011. $545 \mathrm{p}$.

\section{Об авторе}

Тесфалдет Хадгембес Гебре - магистрант департамента строительства, Инженерная академия, Российский университет дружбы народов (Москва, Россия). Область научных интересов: вычислительное строительство, анализ устойчивости рам, расчет на устойчивость, математическое моделирование, устойчивость строительных конструкций. Контактная информация: e-mail tesfaldethg@gmail.com

\section{Для цитирования}

Gebre T.H. The development of chart based method for steel beam designs using the Russian sections (Разpaботка графического метода проектирования стальных балок с помощью диаграмм для российского сортамента стальных профилей) // Строительная механика инженерных конструкций и сооружений. 2018. Т. 14. № 6. C. 495-501. DOI: $10.22363 / 1815-5235-2018-14-6-$ 495-501 